\title{
Students' opinions about teaching of the controversial topics in the social studies classes
}

\author{
Kamil Uygun ${ }^{1}$, Ibrahim Ethem Arslan ${ }^{2}$ \\ ${ }^{1}$ Department of Social Studies Education, Usak University, Turkey \\ ${ }^{2}$ Social Sciences Institute, Usak University, Turkey
}

\section{Article Info \\ Article history: \\ Received Dec 14, 2019 \\ Revised Mar 16, 2020 \\ Accepted Apr 26, 2020}

\section{Keywords:}

Controversial issues

Social studies

Students' opinions

\begin{abstract}
The aim of this study was to determine middle school 7th grade students' opinions on controversial issues. In the research, screening model and quantitative research method has been used. The sample of the study consists of 7th graders from 5 public schools located on the center of Demirci district of Manisa province. The 5-point Likert-type questionnaire prepared with 20 items has been applied to 203 students. The data has been put into the statistical program and analyzed. By determining means, deviations and frequencies of all items in the survey, it has been tabulated and interpreted separately. "Mann Whitney U" and Kruskal Wallis H" tests have been used to find out whether the students' opinions about which subjects can be discussed in the classroom, shows significant difference according to various variables or not. Interpretation of the results has been done by the significance level of 0.5. According to the findings of the research, the topics that the students want to discuss the most in the classroom respectively are human rights, multiculturalism, election system, animal rights and freedom of the press. The topics that the students do not want to discuss in the classroom are terror and violence. When the results of the research has been examined according to various variables; significant differences has been seen in different items, such as: The Gender (Military System, Religious Communities, Fanaticism and Cloning), Reading Books (TV Broadcasts), The Education of Father (Religious Communities, Multiculturalism), The Education of Mother (Military System, Religious Communities and Cloning), Father's Profession (Religious Communities, Fanaticism, Internet and Elections System), Mother's Profession (Religious Communities) and Family Income Status (Internet).
\end{abstract}

This is an open access article under the $\underline{C C B Y-S A}$ license.

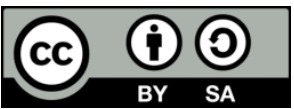

Corresponding Author:

Kamil Uygun,

Department of Social Studies Education,

Usak University,

Ankara İzmir Yolu 8. Km Bir Eylül Kampüsü, Merkez/UŞAK, Turkey.

Email: kamil.uygun@usak.edu.tr

\section{INTRODUCTION}

Individuals create meaning by associating knowledge with real world is one of the basic approaches accepted in today's educational programs [1]. Nations with a culture of democracy have tried to make young people have the necessary skills for the solution of controversial issues by including controversial issues in the curriculum [2]. Controversial issues are based on individualism in pluralism, economic, political and social issues which consisted of various values, interests and different ideas [3]. It is one of the aims of controversial issues to raise critically thinking, effective and purposeful citizens [4]. Teaching controversial 
topics includes a number of important acquisitions for teachers, students and the community [5]. The tendencies of the students who are constantly participating in class and discussion in the classroom are expected to develop as [6, 7]: Make choices in their future lives; Embrace democracy and defends democratic values; Show efficiency in political debates; Follow the political news in the media with attention; Interest in current politics; Feeling the ability to influence state policy increases their self-confidence.

Education and training that prepares children for life has to be familiar with current events and controversial issues. In order to gain knowledge, skills and values to the students, it is necessary to base the topics covered in the course on current and controversial issues and their results [8,9]. Controversial issues are those that contain discussions about beliefs and values, which concern the whole society and which are important to almost all of the society, these Controversial issues are the issues that aren't accepted by the world or on which there isn't any consensus [5]. Controversial issues should be included in the content of social studies course. The matter which one of the aims of social studies, "By being aware of being a part of humanity, shows sensitivity to the issues concerning his/her country and the world" is related to the teaching of controversial subjects. The teachings of controversial subjects in social studies course enables individuals to follow the world more closely and prevents them remain indifferent to the world they live in [10, 11].

The application of opposing views and discussions in a specific perspective and in the setting of the course will be beneficial in the implementation of citizenship education and academic education [12]. Followings are the main reasons why controversial topics are included in the curriculum [13-16]: Increasing students' critical perspectives; Developing social and interpersonal communication skills; Developing students' interests and beliefs as active citizens and increasing their self-confidence; Preparing students for their future life as an effective citizen and to helping them grow as an effective democratic citizen; Making them adopt, internalize the democratic values and demonstrate these functions.

We can say that an education that is not integrated with the social life and that is remained far from the society has happened to be an education that contradicts its own aims. Since one of the prominent goals of the education system is to prepare students for life and to educate them as coping and questioning individuals for the problems that will arise in front of them in a lifetime, Integrating the controversial and current topics into social studies and other branches of social sciences in a planned way is appropriate for the aims of social studies courses to encourage students to generate ideas by brainstorming them [17]. Controversial issues should be included in social studies education programs because of the guiding role of students in dealing with the problems that they might bump into in the future and making the right decisions. Controversial issues' being a part of the social studies education program is explained in eight articles [18, 19]:

"Demonstrating controversial issues within educational institutions rather than outside, being sorter in structuring chaos enriches the educational experience. Discussion can contribute to the learning process when it is usefully managed. It teaches students that they are strong in understanding the democratic diversity of society, placing controversial issues in the secondary plan shows that students are not trusted to be sensitive to the various problems of the community they live in. Placing controversial issues in the background also suggests that other individuals who are even adults in this context, do not know how to deal with the chaos, instead of that, trying to make students and society understand the importance of controversial issues and maintaining their position on the agenda can provide an important shaping task for the functioning of democracy"

The teaching of controversial subjects is very important in order to avoid the range of mistakes starting from the first level of education. It is thought that the upbringing of individuals who can express their thoughts, open to different ideas and without prejudice is extremely important for the future of our country. Providing children, the ability to live with other people in an ever-changing world is one of the most important responsibilities of social studies [20]. The social studies curriculum recommends living in harmony with other people and socializing [21]. It is important to respect different views in order to live in harmony with other people in the community [22]. Respect for differences is essential for intercultural competence [23-27].

\section{RESEARCH METHOD}

The research has been prepared with a screening model. The screening model is one of the most widely used models in social sciences and related applied fields. Screening researches are the processes of asking a lot of people the same questions and examining their answers [28]. The subject of the research has been tried to be defined with the situation that it is in. It has been conducted with the survey technique of quantitative method within the scope of screening model.

Int. J. Eval. \& Res. Educ. Vol. 9, No. 2, June 2020: 335 - 344 


\subsection{Study group}

The sample of the study consists of 203 students attending 7th grades at 5 public middle schools located on the center of Demirci district of Manisa province. The selection of 7 th grade students as a sample has been influenced by the fact that the grade having the highest number of social studies courses and it is the last levels those social studies has been taught. In the sample selection, an appropriate sample has been benefited from. The fact that schools are easily accessible has been effective in selecting them as samples. The Schools in the Sample are as Follows: 75. Y1l Âlime Paşa Middle School, Demirci İmam Hatip Middle School, Fatih Middle School, Makine Kimya Hüseyin Çamtepe Middle School, Ziya Gökalp Nurettin Kelem Middle School. The sample of the study consists of 203 students attending 7th grade of these schools. $54.7 \%$ of the sample $(n=111)$ are male students and $45.3 \%$ of the sample $(n=92)$ are female students. These rates can also be examined in the Table 1 .

\begin{tabular}{|c|c|c|}
\hline Group & $\mathrm{n}$ & $\%$ \\
\hline Male & 111 & 54.7 \\
\hline Female & 92 & 45.3 \\
\hline Total & 203 & 100 \\
\hline
\end{tabular}

\subsection{Data collection and analysis}

An item pool of controversial issues has been formed. The questionnaire containing the items in formed pool has been sent to three experts. Twenty items have been identified in line with the consensus of the experts and these have formed the questionnaire. On this 5-point Likert-type formed questionnaire, there is a personal information form. Alpha reliability coefficient of the questionnaire has been calculated to be, 742. Statistical package program has been used for the analysis of the data obtained from the research. For data analysis, frequency, percentage, standard deviation and arithmetic mean has been used. As a result of the analysis, it has been found that the data doesn't show normal distribution. Since the data doesn't show normal distribution, from non-parametric tests, "Mann Whitney U" and "Kruskal Wallis H" tests have been applied and the results have been interpreted and presented.

\section{RESULTS AND DISCUSSION}

\subsection{Findings regarding the subjects the students want to discuss in social studies course}

When the views of middle school 7 th grade students on controversial issues are examined, the highest opinion is human rights and the lowest is terrorism. All opinions can be seen in the Table 2 . According to the Table 2, the topics that 7 th grade students want to discuss in the classroom respectively are human rights, multiculturalism, election system, animal rights, and freedom of the press, TV broadcasting, media, traffic, and military system and nuclear power plants. The topics that middle school 7 th grade students do not want to discuss in the classroom are terror and violence. The topics that the students are undecided on whether to discuss or not, respectively are: privatization, injustice in income distribution, fanaticism, religious communities and cloning. 
Table 2. Frequency and percentage distribution of students' opinions on controversial topics

\begin{tabular}{|c|c|c|c|c|c|c|c|c|c|c|c|c|}
\hline & \multicolumn{2}{|c|}{$\begin{array}{l}\text { Strongly } \\
\text { Agree }\end{array}$} & \multicolumn{2}{|c|}{ Agree } & \multicolumn{2}{|c|}{ Undecided } & \multicolumn{2}{|c|}{ Disagree } & \multicolumn{2}{|c|}{ Not at All } & \multirow[b]{2}{*}{$\overline{\mathrm{x}}$} & \multirow[b]{2}{*}{$\mathrm{Sd}$} \\
\hline & $\mathrm{f}$ & $\%$ & $\mathrm{f}$ & $\%$ & $\mathrm{f}$ & $\%$ & $\mathrm{f}$ & $\%$ & f & $\%$ & & \\
\hline Military System & 73 & 36.0 & 41 & 20.2 & 46 & 26.2 & 27 & 13.3 & 16 & 7.9 & 2.37 & 1.304 \\
\hline Freedom of the Press & 71 & 35.0 & 60 & 29.6 & 52 & 25.6 & 12 & 5.9 & 8 & 3.9 & 2.14 & 1.087 \\
\hline Religious Communities & 44 & 21.7 & 25 & 12.3 & 58 & 28.6 & 42 & 20.7 & 34 & 16.7 & 2.99 & 1.370 \\
\hline Multiculturalism & 95 & 46.8 & 62 & 30.5 & 32 & 15.8 & 8 & 3.9 & 6 & 3.0 & 1.86 & 1.017 \\
\hline Fanaticism & 32 & 15.8 & 37 & 18.2 & 72 & 35.5 & 42 & 20.7 & 20 & 9.9 & 2.91 & 1.118 \\
\hline Injustice in Income D. & 58 & 28.6 & 33 & 16.3 & 55 & 27.1 & 26 & 12.8 & 31 & 15.3 & 2.70 & 1.401 \\
\hline Migration & 28 & 13.8 & 50 & 24.6 & 63 & 31.0 & 42 & 20.7 & 20 & 9.9 & 2.88 & 1.180 \\
\hline Animal Rights & 90 & 44.3 & 51 & 25.1 & 36 & 17.7 & 18 & 8.9 & 8 & 3.9 & 2.03 & 1.156 \\
\hline Human Rights & 143 & 70.4 & 37 & 18.2 & 12 & 5.9 & 7 & 3.4 & 4 & 2.0 & 1.48 & 0.903 \\
\hline Internet & 83 & 40.9 & 73 & 36.0 & 27 & 13.3 & 13 & 6.3 & 7 & 3.4 & 1.96 & 1.054 \\
\hline Cloning & 36 & 17.7 & 25 & 12.3 & 75 & 36.9 & 36 & 17.7 & 31 & 15.3 & 3.00 & 1.276 \\
\hline Substance Addiction & 53 & 26.1 & 20 & 9.9 & 23 & 11.3 & 36 & 17.7 & 71 & 35.0 & 3.26 & 1.633 \\
\hline Media & 70 & 34.5 & 60 & 29.6 & 49 & 24.1 & 11 & 5.4 & 13 & 6.4 & 2.20 & 1.161 \\
\hline Nuclear Power Plants & 49 & 24.1 & 52 & 25.6 & 59. & 29.1 & 22 & 10.8 & 21 & 10.3 & 2.58 & 1.254 \\
\hline Privatization & 40 & 19.7 & 50 & 24.6 & 75 & 36.9 & 16 & 7.9 & 22 & 10.8 & 2.66 & 1.198 \\
\hline Election System & 93 & 45.8 & 52 & 25.6 & 37 & 18.2 & 11 & 5.4 & 10 & 4.9 & 1.86 & 1.143 \\
\hline Severity & 47 & 23.2 & 25 & 12.3 & 20 & 9.9 & 31 & 15.3 & 80 & 39.4 & 3.35 & 1.163 \\
\hline Terror & 44 & 21.7 & 14 & 6.9 & 22 & 10.8 & 29 & 14.3 & 94 & 46.3 & 3.57 & 1.620 \\
\hline Traffic & 70 & 34.5 & 51 & 25.1 & 49 & 24.1 & 15 & 7.4 & 18 & 8.9 & 2.31 & 1.231 \\
\hline TV Broadcasts & 71 & 35.0 & 68 & 33.5 & 40 & 19.7 & 11 & 5.4 & 13 & 6.4 & 2.15 & 1.151 \\
\hline
\end{tabular}

\subsection{Gender related findings}

Middle school 7th grade students' opinions about controversial issues have been analyzed according to gender variable M1. (Male $\bar{x}=2.16$, Female $\bar{x}=2.62$ ), M3. (Male $\bar{x}=2.67$, Female $\bar{x}=3.37$ ), M5. (Male $\bar{x}=2.70$, Female $\bar{x}=3.15$ ), M11. (Male $\bar{x}=2.73$, Female $\bar{x}=3.34$ ) It has been found out that it shows a significant difference in the favour of female students $(\mathrm{p}<.05)$. These differences can also be examined in Table 3.

Table 3. Mean, standard deviation values and Mann Whitney u test results according to gender variable

\begin{tabular}{cccccc}
\hline & Group & $\mathrm{N}$ & $\overline{\mathrm{x}}$ & $\mathrm{Sd}$ & $\mathrm{p}$ \\
\hline \multirow{2}{*}{ M1 Military System } & Female & 111 & 2.16 & 1.365 & \multirow{2}{*}{0.003} \\
& Male & 92 & 2.62 & 1.185 & \\
\multirow{3}{*}{ M3 Religious Communities } & Female & 111 & 2.67 & 1.384 & \multirow{2}{*}{0.000} \\
& Male & 92 & 3.37 & 1.255 & \\
\multirow{2}{*}{ M5 Fanaticism } & Female & 111 & 2.70 & 1.262 & \multirow{2}{*}{0.008} \\
& Male & 92 & 3.15 & 1.048 & \\
M11 Cloning & Female & 111 & 2.73 & 1.286 & \multirow{2}{*}{0.002} \\
& Male & 92 & 3.34 & 1.189 & \\
\hline
\end{tabular}

\subsection{Findings related to book reading}

When middle school 7th grade students' opinions about controversial issues have been analyzed according to book reading M20. (Yes $\bar{x}=2.22$, No $\bar{x}=1.69$ ) There is a significant difference in favor of book readers $(\mathrm{p}<.05)$. This difference can also be examined in Table 4.

Table 4. Mean, standard deviation values and Mann Whitney U test results

\begin{tabular}{llllll}
\multicolumn{6}{c}{ according to book reading variables } \\
\hline & Group & $\mathrm{N}$ & $\overline{\mathrm{x}}$ & $\mathrm{Sd}$ & $\mathrm{p}$ \\
\hline \multirow{2}{*}{ M20 TV Broadcasts } & Yes & 174 & 2.22 & 1.198 & \multirow{2}{*}{0.041} \\
& No & 29 & 1.69 & 0.060 & \\
\hline
\end{tabular}

\subsection{Findings related to going to private education institutions}

Middle school 7th grade students' opinions about controversial issues have been analyzed according to going to private education institutions; M11. (Yes $\bar{x}=1.83$, no $\bar{x}=3.04$ ) There is a significant difference in favor of those who do not go to private education institutions $(\mathrm{p}<.05)$. This difference can also be examined in Table 5.

Int. J. Eval. \& Res. Educ. Vol. 9, No. 2, June 2020: 335 - 344 
Table 5. Mean, standard deviation values and Mann Whitney U test results according to going to private education institutions variables

\begin{tabular}{cccccc}
\hline & Group & $\mathrm{N}$ & $\overline{\mathrm{x}}$ & $\mathrm{Sd}$ & $\mathrm{p}$ \\
\hline \multirow{2}{*}{ M11. Cloning } & Yes & 6 & 1.83 & 0.753 & \multirow{2}{*}{0.016} \\
& No & 197 & 3.84 & 1.273 & \\
\hline
\end{tabular}

\subsection{Findings related to father's education level}

When the views of middle school 7th grade students on controversial issues were examined according to their father's educational level, a significant differentiation in M3 and M4 was understood after the "Kruskal Wallis H" test. All items were analyzed separately by "Mann Whitney U" test to determine where the difference stems from. As a result:

In M3, between the students whose fathers' education level is "High School, College and University" graduate and the students whose fathers' education level is "Primary School and Middle School" graduate, it has been understood that there is a significant difference in favor of the students whose fathers' education level is "High School, College and University" graduate $(\mathrm{p}<.05)$.

In M4, between the students whose fathers' education level is "College \& University" graduate and the students whose fathers' education level is "Primary School, Middle School and High School", it has been seen that there is a significant difference in favor of the students whose fathers' education level is "College \& University" graduate $(\mathrm{p}<.05)$. These differences can be seen in the Table 6.

Table 6. Mean standard deviation values and Kruskal Wallis $\mathrm{H}$ test results according to father's education level

\begin{tabular}{llllll}
\hline & Group & $\mathrm{N}$ & $\overline{\mathrm{x}}$ & $\mathrm{Sd}$ & $\mathrm{P}$ \\
\hline & Uneducated & - & - & - & \\
& Primary & 72 & 2.74 & 1.434 & \\
& Middle School & 49 & 2.63 & 1.318 & \multirow{5}{*}{0.005} \\
& High School and counterparts & 56 & 3.34 & 1.254 & \\
& College and University & 22 & 3.64 & 1.136 & \\
& Post Graduate & 4 & 3.25 & 1.708 & \\
& Uneducated & - & - & - & \\
& Primary & 72 & 1.76 & 1.041 & \\
& Middle School & 49 & 1.76 & 0.974 & \multirow{2}{*}{0.040} \\
& High School and counterparts & 56 & 1.86 & 0.883 & \\
& College and University & 22 & 2.50 & 1.263 & \\
& Post Graduate & 4 & 1.25 & 0.500 & \\
\hline
\end{tabular}

\subsection{Findings related to mother's education level}

When the views of middle school 7th grade students on controversial issues were examined according to their mothers' educational level, a significant differentiation in M1, M3 and M11 was understood after the "Kruskal Wallis H" test. All items were analyzed separately by "Mann Whitney U" test to determine where the difference stems from. As a result:

In M1, between the students whose mothers' education level is "Primary School" graduate and the students whose mothers' education level is "High School" graduate, it has been understood that there is a significant difference in favor of the students whose mothers' education level is "Primary School" graduate $(\mathrm{p}<.05)$.

In M1, between the students whose mothers' education level is "Middle School" graduate and the students whose mothers' education level is "High School, College and University" graduate, it has been seen that it shows an important difference in favor of the students whose mothers' education level is "Middle School" graduate $(\mathrm{p}<.05)$.

In M3, between the students whose mothers' education level is "Primary School" graduate and the students whose mothers' education level is "College and University" graduate, it has occurred that there is a remarkable difference in favor of the students whose mothers' education level is "Primary School" graduate $(\mathrm{p}<.05)$.

In M3, between the students whose mothers' education level is "Middle School" graduate and the students whose mothers' education level is "High School, College and University" graduate, it has been seen that it shows an impressive difference in favor of the students whose mothers' education level is "Middle School" graduate $(\mathrm{p}<.05)$. 
In M11, a noteworthy difference has been shown in favor of the students whose mother's education level is "Uneducated" as compared to the students whose mother's education level is "College and University" $(\mathrm{p}<.05)$.

In M11, a significant difference has been shown in favor of the students whose mother's education level is "Primary School and Middle School" graduate as compared to the students whose mother's education level is "High School, College and University" $(\mathrm{p}<.05)$. These differences can be seen in the Table 7.

Table 7. Mean, standard deviation values and Kruskal Wallis $\mathrm{H}$ test results according to mother's education level

\begin{tabular}{clllll}
\hline & Grup & $\mathrm{N}$ & $\overline{\mathrm{x}}$ & $\mathrm{Sd}$ & $\mathrm{p}$ \\
\hline & Illiterate & 4 & 2.25 & 1.258 & \\
& Primary & 102 & 2.26 & 1.297 & \\
& Middle School & 51 & 2.02 & 1.157 & 0.006 \\
& High School and counterparts & 29 & 3.03 & 1.322 & \\
& College and University & 15 & 2.80 & 1.136 & \\
& Post Graduate & 2 & 4.00 & 1.414 & \\
& Illiterate & 4 & 2.75 & 1.708 & \\
& Primary & 102 & 2.87 & 1.460 & \\
M3. Religious Communities & Middle School & 51 & 2.75 & 1.146 & 0.046 \\
& High School and counterparts & 29 & 3.34 & 1.317 & \\
& College and University & 15 & 3.80 & 1.146 & \\
& Post Graduate & 2 & 4.00 & 1.414 & \\
& Illiterate & 4 & 3.75 & .957 & \\
& Primary & 102 & 3.08 & 1.246 & \\
& Middle School & 51 & 3.25 & 1.214 & 0.017 \\
& High School and counterparts & 29 & 2.48 & 1.299 & \\
& College and University & 15 & 2.33 & 1.175 & \\
& Post Graduate & 2 & 4.00 & 1.414 & \\
\hline
\end{tabular}

\subsection{Findings related to father's profession status variable}

When the views of middle school 7th grade students on controversial issues were examined according to their Father's profession status, a significant differentiation in M3, M5, M10 and M16 was understood after the "Kruskal Wallis H" test. All items were analyzed separately by "Mann Whitney U" test to determine where the difference stems from. As a result:

In M3, a significant difference has been seen in favor of the students whose father's profession is "Civil Servant" as compared to the students whose father's profession is "Laborer and Farmer" $(\mathrm{p}<.05)$.

In M5, a noticeable difference has occurred in favor of the students whose father's profession is "Civil Servant and Self Employed" out of "Civil Servant and Self-Employed" as compared to the students whose father's profession is "Laborer" $(\mathrm{p}<.05)$.

In M5, an impressive difference has been found out in favor of the students whose father's profession is "Farmer" as compared to the students whose father's profession is "Laborer and Retired" $(\mathrm{p}<.05)$.

In M10, a big difference has been shown in favor of the students whose father's profession is "Farmer" as compared to the students whose father's profession is "Civil Servant, Laborer, Shopkeeper, Retired and Self-Employed" $(\mathrm{p}<.05)$.

In M16, a remarkable difference has been seen in favor of the students whose father's profession is "Laborer" as compared to the students whose father's profession is "Farmer" $(\mathrm{p}<.05)$.

In M16, an important difference has been calculated in favor of the students whose father's profession is "Self-Employed" as compared to the students whose father's profession is "Civil Servant and Farmer" $(\mathrm{p}<.05)$. These differences can be seen in Table 8. 
Table 8. Mean, standard deviation values and Kruskal Wallis H test results according to father's profession status

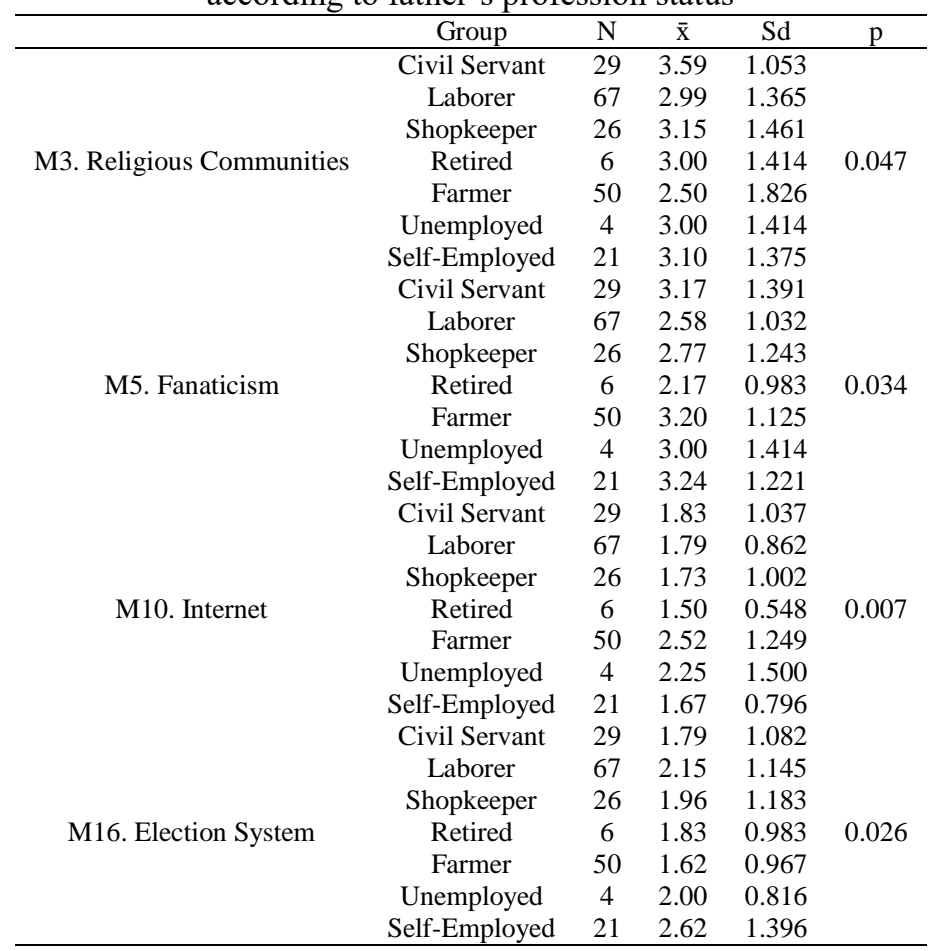

\subsection{Findings related to mother's profession status}

When the views of middle school 7th grade students on controversial issues were examined according to their mother's profession status, a significant differentiation in M3, M5, M10 and M16 was understood after the "Kruskal Wallis H" test. All items were analyzed separately by "Mann Whitney U" test to determine where the difference stems from. As a result:

In M16, an impressive difference has been noted in favor of the students whose mother's profession is "Housewife" as compared to the students whose mother's profession is "Laborer" ( $p<.05)$. These differences can be seen in the Table 9 .

Table 9. Mean, standard deviation values and Kruskal Wallis $\mathrm{H}$ test results

\begin{tabular}{llllll}
\multicolumn{7}{c}{ according to mother's profession status } \\
\hline & Group & $\mathrm{N}$ & $\overline{\mathrm{x}}$ & $\mathrm{Sd}$ & $\mathrm{p}$ \\
\hline & Civil Servant & 16 & 3.38 & 1.204 & \\
& Laborer & 14 & 3.71 & 1.383 & \\
& Shopkeeper & 2 & 4.50 & 0.707 & \multirow{5}{*}{ M3. Religious Communities } \\
& Retired & 1 & 3.34 & 1.254 & 0.039 \\
& Farmer & 170 & 2.86 & 1.363 & \\
& Unemployed & - & - & - & \\
\hline
\end{tabular}

\subsection{Findings related to family income status}

When the views of middle school 7th grade students on controversial issues were examined according to their family income status, a significant differentiation in M10 was understood after the "Kruskal Wallis H" test. All items were analyzed separately by "Mann Whitney U" test to determine where the difference stems from. As a result:

In M10, an impressive difference has been calculated in favor of the students whose family income status is between "1000-1999" as compared to the students whose family income status is between "20002999 and 3000-3999" ( $(\mathrm{p}<.05)$. These differences can be seen in the Table 10. 
Table 10. Mean, standard deviation values and Kruskal Wallis $H$ test results according to family income status

\begin{tabular}{llllll}
\hline & Group & $\mathrm{N}$ & $\bar{X}$ & Ss & $\mathrm{p}$ \\
\hline \multirow{5}{*}{ M10. Internet } & $0-999$ & 30 & 2.13 & 1.224 & \\
& $1000-1999$ & 33 & 2.45 & 1.175 & \\
& $2000-2999$ & 83 & 1.78 & 0.842 & 0.041 \\
& $3000-3999$ & 30 & 1.73 & 1.048 & \\
& $4000-4999$ & 10 & 1.80 & 1.033 & \\
& 5000 and upper & 17 & 2.00 & 1.225 & \\
\hline
\end{tabular}

\subsection{Discussion}

In the research that $[1,17]$ did, primary school intern teachers stated that one of the most important topics that they want to be brought into class and discussed is "Human Rights." In our research we did, the first issue that students want to discuss in the classroom is "Human Rights". According to these results, we can say that the first issue that primary school intern teachers and the students want to discuss in the class is "Human Rights" and there is a parallelism between these two groups. In the same research, "Military System", "Religious Communities", "Fanaticism", and "Cloning" are among the last 10 issues that primary school intern teachers want to bring into the class and discuss. These subjects are in common in both studies conducted. According to the research we can say that students are undecided about discussing the issues "Religious Communities", "Fanaticism", and "Cloning" but they want to discuss the issue "Military System" in the class.

In the research that Copur [29] did, it is seen that "Freedom of the Press", "Multiculturalism", "Violence", "Traffic" and "TV Broadcasts" are among the first 10 issues that primary school teachers want to be discussed in the class. In the research we have carried out, it has occurred that students also want to discuss the issues "Freedom of the Press", "Multiculturalism", "Traffic", and "TV Broadcasts", which are the issues that social studies teachers want to deal with in the class. According to the findings we have from our research, it can be said that "Violence", which is one of the topics that social studies teachers want to deal with in the classroom, is not wanted to be discussed in the class by the students. It has been seen that "Military System" and "Religious Communities" are among the last issues that social studies teachers want to discuss in the class. The result has appeared that in the research [29] has carried out, social studies teachers don't want to discuss "Military System" but in this research that we have carried out, instead of teachers, students want to discuss it in the class. Since the issue Religious Communities' being put at the end of the discussion list in the class by social studies teachers and also as a result of the students' being undecided to discuss this issue, it can be said that the views of teachers and students are in the same direction.

In the research that [11] has done, the controversial issues that social studies teachers have discussed in the classroom are as follows: "Human Rights", "Internet", "TV Broadcasts" and "Violence". In the research we have carried out, it has been seen that students also want to discuss the issues "Human Rights", "Internet" and "TV Broadcasts", which are the issues that social studies teachers want to deal with in the class. On contrary to the teacher's view, according to the information obtained from our study, it can be said that students do not want to discuss it in the lesson.

It is seen in Öztürk's study [11], "Military Service", "Religious Communities" and "Cloning" are among the subjects that social studies teachers bring to the classroom at least or don't want to bring. By looking at the results of the study, we can say that teachers don't want to discuss "Military System" in the classroom According to the results of our study, instead of teachers, we can say that students want to discuss this issue in the class. Social studies teachers have enclosed that they do not want to deal with "Religious Communities" and "Cloning" items in the classroom. According to the results of our research, students have stated that they are undecided to discuss these items. According to these results, we can say that teachers' and students' opinions show parallelism. According to social studies teacher candidates, the most controversial issues are social problems. The most controversial issue is unemployment [30]. History teachers want to discuss the reforms of the Atatürk period, military coups, Armenian and the Cyprus issue [31]. In order for the teaching of controversial issues to be effective, teachers and teachings need to be developed [32]. If a suitable environment is prepared, healthy discussions are provided and useful for social studies teaching [33]. 


\section{CONCLUSION}

When the results of the research are outlined, "Human Rights" is the subject that the students want to discuss the most in the classroom. The issue of human rights which contributes to the role of social studies in raising "effective citizens and individuals who have embraced democracy" is one of the basic issues in social studies.

"Terror" is one of the main topics that students don't want to discuss in the class. The issue of terrorism is one of the most frequent issues on the agenda of our country and in the media. We can say that students are not willing to discuss this issue in class because of the negative effects of terrorism on people and the tense atmosphere it leaves on society.

As a result of the research, the topics that the students want to discuss the most in the classroom respectively are "Human Rights", "Multiculturalism", "Election System", "Animal Rights", "Freedom of the Press", "TV Broadcasts", "Media", "Traffic", "Military System" and "Nuclear Plants".

According to the findings obtained from the research, the topics that the students are undecided on whether to discuss or not, respectively; "Privatization", "Injustice in Income Distribution", "Fanaticism", "Religious Communities" and "Cloning". According to the results of the study, the topics students do not want to discuss in the classroom are "Terror" and "Violence".

The research is limited to 5 public middle schools in total and to 7 th grade students who are attending to these schools at center of Demirci district in Manisa province. The same study can be conducted in different regions and at different grade levels. This study has been conducted in the screening model as a quantitative study. This research can be applied by being supported with a qualitative research. During the research, it has been witnessed that few studies carried out on controversial issues. Any studies haven't been met with about controversial issues for students. We can recommend to be carried out wider and more comprehensive researches on these issues. By adding teacher opinions, a more detailed study can be done covering the opinions of students and teachers.

\section{ACKNOWLEDGEMENTS}

This study was produced from the master thesis of the second author under the supervision of the first author.

\section{REFERENCES}

[1] F. Seçgin, "The teacher candidates? Perception, attitude and ideas about teaching the controversial issues," (Unpublished master's thesis), Gaziosmanpasa University, Social Sciences Institute, Tokat, 2009.

[2] R. Cross and R. Price, "Science teacher's social conciense and the role of teaching controversial issues in the teaching of science," Journal of Research in Science Teaching, vol. 33, no. 3, pp. 319-333, 1996.

[3] T. L. Dynneson and R.E. Gross, Desingning effective instruction for secondary social studies. Upper Saddle River, NJ: Prentice-Hall, Inc, 1999.

[4] J. H. James, "Reframing the disclosure debate: confronting 1ssues of transparency in teaching controversial issues," Social Studies Resarch and Practice, vol. 4, no. 1, pp. 82-93, 2009.

[5] M. Avaroğulları, "An action research regarding controversial issues in social studies instruction," NWSAEducation Sciences, vol. 10, 2, pp. 139-150, 2015.

[6] K. Barton and A. McCully, "Teaching controversial 1ssues. Where controversial issues realy matter," Teachin History, 2007.

[7] Ö. Akman and U. Bastık, "The concept of family as a controversial issue in social studies textbooks: A content analysis," Trakya University. Journal of Education Facult, vol. 6, no. 2, pp. 247-263, 2016.

[8] H. Gedik, "Using current events in elementary social studies courses and the views of students," Ahi Evran University. Journal of Kırşehir Education Faculty, vol. 11, no. 2, pp. 97-118, 2010.

[9] C. Binbaşıŏlu, "Eğitimde günlük olaylar ve öğretimi," Çağdaș Eğitim Dergisi,Sayl, vol. 315, pp. 14-16, 2004.

[10] MEB, Sosyal Bilgiler dersi öğretim programı (İlkokul ve Ortaokul 4, 5, 6 ve 7. Sinıflar), Milli Eğitim Bakanlığı Yayınları, Ankara, 2018.

[11] D. Öztürk, "Social studies teachers' views and practices on teaching of controversial issues," (Unpublished doctoral thesis), Kastamonu University Social Sciences Institute, Kastamonu, 2017.

[12] T. C. King, "Teaching and learning about controversial issues: lessons from northern 1reland," Theory and Resarch in Social Education, vol. 37, pp. 215-246, 2009.

[13] Asimeng and L. Boahene, "Creating strategies to deal with problems of teaching controversial issues in social studies education in african schools," Intercultural Education, vol. 18, no. 3, pp. 231-242, 2007.

[14] C. L. Hahn, "Controversial 1ssues in social studies," In. J.P. Shaver (Ed), Handbook of Research on Social Studies Teaching and Learning s.470-480, NewYork: Macmillan, 1991.

[15] A. M. Harwood and C.L. Hahn, "Controversial 1ssues in the classroom. (Eric Digest)," Clearinghouse for Social Studies/Social Science Education. Bloomington, IN, 1990.

[16] K. Y1lmaz, "Investigation into controversial issues and taboo topics: social studies teachers' perspectives," Mustafa Kemal University Journal of Social Sciences Institute, vol. 9, no. 18, pp. 201-225, 2012. 
[17] S. Yazıcı and F. Seçgin, "A study on teaching controversial issues," The Journal of International Social Research, vol. 3, no. 12, pp. 488-501, 2010.

[18] E. Wilson, C. Sunal, M. Haas, and M. Lauglin, Teachers perspectives on incorporating current controversial issues into the curriculum, Paper Presented at the Annual Meeting of the National Council for Social Studies. 79th, Orlando, FL, November, pp. 19-21, 1999.

[19] B. Alagöz, "Developing a controversial issues scale toward social studies teacher candidates: The study of validity and reliability," Gaziantep University Journal of Social Science, vol. 13, no. 3, pp. 735-766, 2014.

[20] D. O. Smith, "Current events in the intermediate grades of a modern elemantry school," (MS Thesis, Kean University), New Jersey, 1963.

[21] K. Uygun, "Sosyal bilgiler programı ve yapılandırmacılık," H. Çalışkan \& B. Kılcan (Ed.), Sosyal bilgiler öğretimi (ss. 54-86). İstanbul: Lisans Yayıncılık, 2018.

[22] E. Görmez, "The views of middle school students who have taken social studies course on respect for differences," Kastamonu Education Journal, vol. 27, no. 5, pp. 2077-2088, 2018.

[23] A. Koc and H. Duygu, "Acquisition of middle school student's respect to differences and adaptation skills with foreign students," Journal of Innovative Research in Social Studies, vol. 1, no. 1, pp. 38-51, 2018.

[24] N. Ogut, Investigation of the relationship between intercultural sensitivity level and ethnocentrism, life satisfaction and happiness levels (Unpublished doctoral thesis), Selcuk University Social Sciences Institute, Konya, 2018.

[25] A. Temel Eginli and M. Yalcin, "Developing Intercultural Competence and Intercultural Adjustment," Global Media Journal TR Edition, vol. 7, no. 13, pp. 6-27, 2016.

[26] A. Temel Eginli, "The importance of the training of cultural diversity in obtaining intercultural competency," Öneri Dergisi, vol. 9, no. 35, pp. 215-227, 2012.

[27] Ş. Uzunaslan and E. Gökcearslan Çifci, "Importance of improving cultural competence in social work practices," Society and Social Work, vol. 30, no. 1, pp. 213-230, 2019.

[28] W. L. Neuman, Toplumsal araştırma yöntemleri II, (Çev. S. Özge), Ankara: Yayınodası, 2014.

[29] Ahmet Çopur, "A review on the opinions of social studies teachers on teaching controversial issues," (Unpublished master's thesis), Uludag University, Educational Sciences Institute, Bursa, 2015.

[30] H. Tuncer, "Examining social studies teacher candidates' opinions about teaching controversial subjects," (Unpublished master's thesis), Firat University, Educational Sciences Institute, Elazığ, 2018.

[31] I. Demircioğlu, "Using controversial issues in history lessons: Views of Turkish history teachers," Kastamonu Education Journal, vol. 24, no. 1, pp. 147-162, 2016.

[32] J. Byford, S. Lennon, and W. B. Russell III, "Teaching controversial issues in the social studies: A research study of high school teachers," Cleaning House: A Journal of Educational Strategies, Issues and Ideas, vol. 84, no. 4, pp. 165-170, 2009.

[33] T. Lintner, "The controversy over controversy in the social studies classroom," Southeastern Regional Association of Teacher Educators (SRATE) Journal, vol. 27, no. 1, pp. 14-21, 2018.

Int. J. Eval. \& Res. Educ. Vol. 9, No. 2, June 2020: 335 - 344 